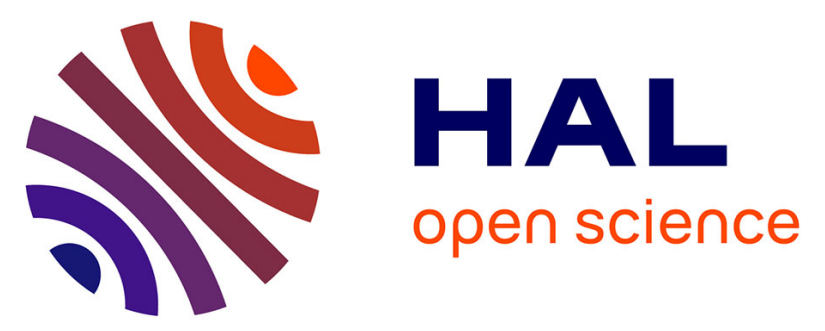

\title{
Non-covalently generated 3D supramolecular crystal structure in a new family of hybrid nitrates templated by piperazine: Thermal behavior and in vitro antimicrobial potential
}

D. Ben Hassan, W. Rekik, A. Otero-De-La Roza, F. Ben Mefteh, T. Roisnel, T. Bataille, H. Naïli

\section{To cite this version:}

D. Ben Hassan, W. Rekik, A. Otero-De-La Roza, F. Ben Mefteh, T. Roisnel, et al.. Non-covalently generated 3D supramolecular crystal structure in a new family of hybrid nitrates templated by piperazine: Thermal behavior and in vitro antimicrobial potential. Polyhedron, 2016, 119, pp.238-247. 10.1016/j.poly.2016.08.043 . hal-01381134

HAL Id: hal-01381134

https://hal-univ-rennes1.archives-ouvertes.fr/hal-01381134

Submitted on 18 Nov 2016

HAL is a multi-disciplinary open access archive for the deposit and dissemination of scientific research documents, whether they are published or not. The documents may come from teaching and research institutions in France or abroad, or from public or private research centers.
L'archive ouverte pluridisciplinaire HAL, est destinée au dépôt et à la diffusion de documents scientifiques de niveau recherche, publiés ou non, émanant des établissements d'enseignement et de recherche français ou étrangers, des laboratoires publics ou privés. 


\section{Polyhedron}

\section{Non-covalently generated 3D supramolecular crystal structure in a new family of hybrid nitrates templated by piperazine: thermal behavior and in vitro antimicrobial potential}

Dhouha Ben Hassan ${ }^{\mathrm{a}}$, Walid Rekik ${ }^{\mathrm{a}}$, Alberto Otero-de-la Roza ${ }^{\mathrm{b}}$, Fedia Ben Mefteh ${ }^{\mathrm{c}}$, Thierry Roisnel $^{\mathrm{d}}$, Thierry Bataille ${ }^{\mathrm{e}}$ and Houcine Naîli ${ }^{\mathrm{a}, *}$

${ }^{a}$ : Laboratoire Physicochimie de l'État Solide, Département de Chimie, Faculté des Sciences de Sfax, Université de Sfax, BP 1171, 3000, Tunisia.

${ }^{\mathrm{b}}$ : National Institute for Nanotechnology, National Research Council of Canada, 11421Saskatchewan Drive, Edmonton, Alberta Canada T6G 2 M9.

${ }^{c}$ : Laboratory of plant biotechnology. Faculty of sciences, University of Sfax, B.P 1171, 3000, Tunisia.

${ }^{\mathrm{d}}$ : Institut des Sciences Chimiques de Rennes (ISCR), UMR 6226 CNRS-Université de Rennes 1, Campus de Beaulieu, 263 avenue du General Leclerc, Bat 10A, 35042 Rennes Cedex, France.

${ }^{\mathrm{e}}$ : Ecole Nationale Supérieure de Chimie de Rennes, 11 Allée de Beaulieu F-35708 RENNES cedex 7 , France.

*Corresponding author:

E-mail address: houcine_naili@yahoo.com

Tel: +216 986600 26; fax: +21674274437 


\section{Graphical abstract}

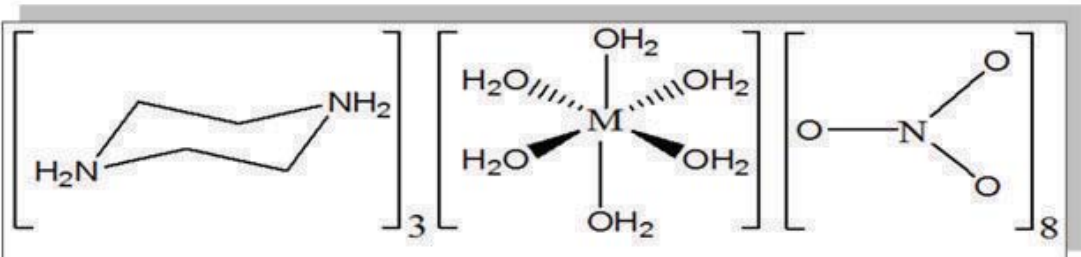

$\mathcal{M}: \mathcal{M n}, \mathrm{Cu}, \mathrm{Co}$

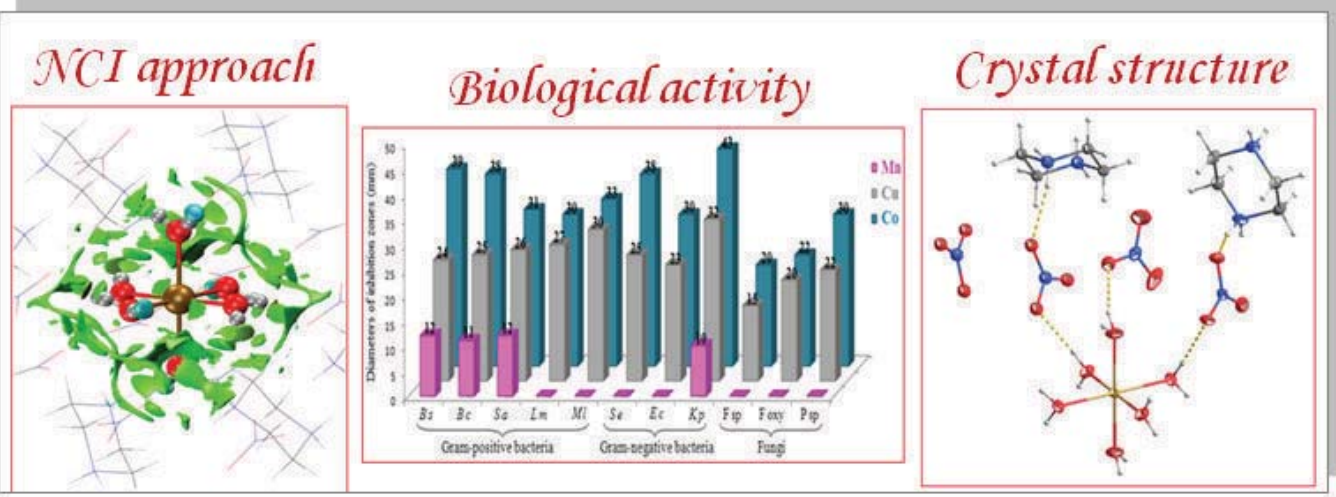

\section{Synopsis}

Three new hybrid nitrates have been successfully prepared. The non-covalent interactions existing in the crystal structures have been illustrated by the NCI approach. The antibacterial and antifungal activities have been evaluated.

\section{Highlights:}

- A new family of hybrid nitrates has been discovered.

- The X-ray diffraction showed isotype supramolecular crystal structures.

- Crystalline metal oxide phases were the final products of the thermal decomposition.

- The NCI approach elucidated the non-covalent interactions in the real space.

- The in vitro anti-bacterial and anti-fungal potentials were evaluated. 


\section{Abstact}

Three new hybrid nitrate materials based on transition metals and templated by piperazine, $\left(\mathrm{C}_{4} \mathrm{H}_{12} \mathrm{~N}_{2}\right)_{3}\left[\mathrm{M}^{\mathrm{II}}\left(\mathrm{H}_{2} \mathrm{O}\right)_{6}\right]\left(\mathrm{NO}_{3}\right)_{8}$ with $\mathrm{M}^{\mathrm{II}}$ : $\mathrm{Mn}(\mathbf{1}), \mathrm{Cu}(\mathbf{2})$ and $\mathrm{Co}(\mathbf{3})$ have been investigated and crystallographically characterized. The single crystal X-ray diffraction study shows that the three complexes crystallize in the triclinic system, space group P $\overline{1}$. Within the adopted supramolecular structures, isolated entities $\left[\mathrm{M}^{\mathrm{II}}\left(\mathrm{H}_{2} \mathrm{O}\right)_{6}\right]^{2+}, \mathrm{NO}_{3}{ }^{-}$and $\left(\mathrm{C}_{4} \mathrm{H}_{12} \mathrm{~N}_{2}\right)^{2+}$ are held together through an extensive $\mathrm{H}-$ bonded system forming a three-dimensional network. The thermogravimetric analysis and temperaturedependent X-ray diffraction (TDXD) were used to follow the thermal behavior of the compounds. The TG analysis shows that, under heating, the precursors decompose into $\mathrm{M}_{2} \mathrm{O}_{3}$ via two steps: a dehydration followed by a total decomposition. The nature of the intermediate phases was studied using TDXD analysis. The orientation and strength of the non-covalent interactions binding the crystal, particularly the hydrogen bond network, were examined using density-functional theory (DFT) electron density and the non-covalent interaction (NCI) plot technique. The synthesized compounds were screened for antibacterial and antifungal activities against five Gram-positive, three Gram-negative bacteria and three fungi.

Key words: hybrid nitrate, H-bonded system, non-covalent interactions, biologic activity. 


\section{Introduction}

Recently, the crystal arrangement and the design of solid-state materials have become areas of great interest [1-5]. During the last few years, several types of non-covalent interactions of varying strengths, such as coordination bonding [4,5], versatile hydrogen interactions [6-9], $\pi-\pi$ stacking $[10,11]$ and electrostatic interactions $[12,13]$ have been recognized and used in constructing extended supramolecular architectures. Until now, the most important driving forces within crystal structures are coordination bonding and hydrogen bonding interactions. Materials having supramolecular architectures, in which transition metal complexes are linked through anions via hydrogen bonds, have attracted attention over the last few years due to their fascinating structures and their exciting properties such as their ability to catalyze specific reactions [14]. In this type of compounds, the anionic groups have shown to play a very important role in the synthesis of a wide range of compounds. So that, creating structures by the use of anions has become a well known synthetic strategy. The literature is rich with a large number of hybrids involving different anionic groups that play a major role in the supramolecular networks especially as hydrogen bonds donors. We report for example a few number of hybrids containing sulfates [15-19], selenates [20-22], perchlorates [23-25] etc... Nitrate anion $\mathrm{NO}_{3}{ }^{-}$has also been used in a large number of structures due to its ability to form non-covalent interactions such as hydrogen bonds by donating oxygen atoms via their lone electron pairs [26-29]. A literature search shows that, nitrate anion is present in a very large number of organometallic compounds as ligand $\left[\mathrm{ML}\left(\mathrm{NO}_{3}\right)_{\mathrm{x}}\right] \cdot \mathrm{nH}_{2} \mathrm{O}$ [30-32], free anion $[\mathrm{ML}]\left(\mathrm{NO}_{3}\right)_{\mathrm{x}} \cdot \mathrm{nH}_{2} \mathrm{O}[33-37],[\mathrm{M}(\mathrm{L}-\mathrm{H})]\left(\mathrm{NO}_{3}\right)_{\mathrm{x}} \cdot \mathrm{nH}_{2} \mathrm{O}$ [38], or both $\left[\mathrm{ML}\left(\mathrm{NO}_{3}\right)_{\mathrm{x}}\right]\left(\mathrm{NO}_{3}\right)_{\mathrm{y}} \cdot \mathrm{nH}_{2} \mathrm{O}[39,40]$ with $\mathrm{n}$ $=0$ for anhydrous compounds. The complexes characterized by the presence of nitrate as counterion showed diverse types of crystal structures with interesting biological, catalytic and magnetic properties $[36,38]$. Thus, having supramolecular structures with free entities like nitrates and free organic molecules is of great interest. We report in the present paper, a new family of compounds whose structures involve free nitrates, metallic complexes and protonated piperazine molecule with hydrogen bond networks forming the 3D supramolecular structures. 


\section{Experimental}

\section{Chemical preparation}

All the title compounds were prepared by the slow evaporation method. In the first step, the piperazine hexahydrate $(1 \mathrm{mmol} / 0.086 \mathrm{~g})$ was dissolved in a minimum amount of distilled water to afford a colorless solution. Under magnetic stirring, the nitric acid $\mathrm{HNO}_{3}(2 \mathrm{mmol} / 0.126 \mathrm{~g})$ and the metal nitrates $\mathrm{M}^{\mathrm{II}}\left(\mathrm{NO}_{3}\right)_{2} \cdot \mathrm{nH}_{2} \mathrm{O}\left(1 \mathrm{mmol} / 0.251 \mathrm{~g}\right.$ of $\mathrm{Mn}\left(\mathrm{NO}_{3}\right)_{2} \cdot 4 \mathrm{H}_{2} \mathrm{O}, 0.243 \mathrm{~g}$ of $\mathrm{Cu}\left(\mathrm{NO}_{3}\right)_{2} \cdot 3 \mathrm{H}_{2} \mathrm{O}$ and $0.291 \mathrm{~g}$ of $\mathrm{Co}\left(\mathrm{NO}_{3}\right)_{2} \cdot 6 \mathrm{H}_{2} \mathrm{O}$ for compound (1), (2) and (3) respectively) were added. Colorless, blue and pink crystals were grown in the solutions corresponding to (1), (2) and (3), respectively. Suitable single crystals were chosen for X-ray diffraction analysis. Anal. Calc. for (1) C: 15.59; N: 21.22; O: 51.97; H: 5.19 (yield: 86 \%); for (2) C: 15.44; N: 21.02; O: 51.49; H: 5.14 (yield: $81 \%$ ) and for (3) C: 15.52; N: 21.13; O: 51.74; H: 5.17 (yield: $69 \%$ ).

\section{Spectroscopic analysis}

The infrared measurements were obtained using a Perkin Elmer FT-IR spectrometer. The samples were diluted with spectroscopic grade $\mathrm{KBr}$ and pressed into a pellet and the scans were run over the range of $500-4000 \mathrm{~cm}^{-1}$.

\section{$X$-ray single crystal diffraction and structure determination}

The title materials crystallize in the triclinic system, space group Pī. X-ray diffraction data were collected at low temperature $(\mathrm{T}=150 \mathrm{~K})$ on single crystal using an APEXII Bruker-AXS diffractometer. The reflection data were acquired using graphite-monochromated $\mathrm{K} \alpha(\mathrm{Mo})$ radiation $(\lambda=0.71073 \AA$ ). The peak integration, frame scaling and corrections for Lorentz-polarization were carried out with the program Bruker SAINT [41]. A multi-scan absorption correction was applied to the intensity values using SADABS program [42]. 
The metallic atoms were located using the direct methods with the SIR97 program [43]. The positions of all the rest non-hydrogen atoms were determined from successive Fourier calculations using SHELXL2014 program [44]. These programs are available in the WinGX interface [45]. All the hydrogen atom positions of water molecules were located in a difference map and refined with distance restraints $\mathrm{O}-\mathrm{H}$ and $\mathrm{H}-\mathrm{H}$ of 0.85 and $1.38 \AA$, respectively. For the piperazine moiety, all the hydrogen atoms bonded to the carbon were positioned geometrically where those bonded to the nitrogen atoms were located after successive Fourier calculations.

The chemical formula obtained after the structural refinement is $\left(\mathrm{C}_{4} \mathrm{H}_{12} \mathrm{~N}_{2}\right)_{3}\left[\mathrm{M}^{\mathrm{II}}\left(\mathrm{H}_{2} \mathrm{O}\right)_{6}\right]\left(\mathrm{NO}_{3}\right)_{8}$ with $\mathrm{M}^{\mathrm{II}}$ : $\mathrm{Mn}(\mathbf{1}), \mathrm{Cu}(\mathbf{2})$ and $\mathrm{Co}(\mathbf{3})$. Tris(piperazinediium) hexaaquamanganese(II) nitrate, tris(piperazinediium) hexaaquacopper(II) nitrate and tris(piperazinediium) hexaaquacobalt(II) nitrate were the full names relative to the $\mathrm{Mn}, \mathrm{Cu}$ and $\mathrm{Co}$ compounds.

\section{Thermogravimetric (TG) and temperature-dependent $X$-ray diffraction (TDXD) analysis}

The TG measurements for the three compounds were performed using a Perkin-Elmer Pyris 6 TGA instrument. The samples of the three compounds were heated from 30 to $500{ }^{\circ} \mathrm{C}$ with a heating rate of 5 ${ }^{\circ} \mathrm{C} \cdot \mathrm{min}^{-1}$ under air atmosphere.

The temperature-dependent X-ray powder diffraction (TDXD) was carried out with a $\theta-\theta$ Bruker AXS D8 Advance powder diffractometer which is equipped with a high-temperature Anton Paar HTK1200 oven camera and a LynxEye detector. The powder patterns were collected using the $\mathrm{Cu}\left(\mathrm{K} \alpha_{1}\right)$ radiation $(\lambda$ $=1.5406 \AA$ ) selected with a graphite monochromator from ambient to $500{ }^{\circ} \mathrm{C}$ with a heating rate of 21.6 ${ }^{\circ} \mathrm{C} \cdot \mathrm{h}^{-1}$.

\section{The NCI method}

The NCI calculations, as a computational technique recently applied to solid state compounds, use qualitative density functional theory and allow for the location and visualization of the non-covalent 
interactions, like hydrogen bonds and weak ionic and Van Der Waals interactions, which occur in regions characterized by small electron density ( $\rho$ ) and reduced density gradient (S) as its first derivative.

The electron densities for the title compounds at their experimental crystal structures were calculated using density-functional theory (DFT) with the Quantum ESPRESSO program [46]. The calculation parameters were 80 Ry for the plane-wave expansion cutoff, 800 Ry for the density cutoff, and a 4x4x4 kpoint grid. The Perdew-Burke-Ernzerhof functional [47] was used. For the Co crystal only, we used cold smearing [48] with a smearing parameter of $0.01 \mathrm{Ry}$. The calculated self-consistent electron densities were used with the NCI plot technique [49,50] as implemented in the Critic2 program [51,52].

\section{Biological study}

The in vitro biological activity of the title compounds was studied to evaluate their potential as antibacterial and antifungal agents using the well diffusion method against eight bacteria and three fungi. The used Gram-positive bacteria are Bacillus subtilis JN934392 (Bs), Bacillus ceureus JN934390 (Bc), Staphylococcus aureus ATCC6538 (Sa), Listeria monocytogenes ( Lm) and Micrococcus luteus (Ml), and the Gram-negative ones are Salamonella enteric serotype Enteritidis ATCC43972 (Se), Escherichia Coli ATCC25922 (Ec) and Klebsiella pneumonia (Kp). The antifungal test was performed against Fusarium sp JX391934 (Fsp), Fusarium oxysporum AB586994 (Foxy) and Pythium sp AY598675 (Psp) fungi. In a typical procedure, wells were made on the agar medium after inoculation with microorganism's cultures in petri plates containing, respectively, Mueller-Hinton Agar and Potato-Dextrose Agar for antibacterial and antifungal tests. Each well was filled with $60 \mu \mathrm{L}$ of the test aqueous solutions at different concentrations $\left(50,100\right.$ and $150 \mathrm{mg} / \mathrm{mL}$ ) of each compound. After diffusion for two hours at $4{ }^{\circ} \mathrm{C}$, the plates were incubated at $37{ }^{\circ} \mathrm{C}$ for $24 \mathrm{~h}$ and at $30{ }^{\circ} \mathrm{C}$ for $72 \mathrm{~h}$ respectively for antibacterial and antifungal tests. In order to prove the activity of the synthesized complexes, aqueous solutions concentrated at 150 $\mathrm{mg} / \mathrm{mL}$ of the piperazine, manganese nitrate, copper nitrate and cobalt nitrate were tested against the used bacteria and fungi with the same procedure and at the same conditions. The antimicrobial activity was estimated by measuring, in millimeters, the diameters of the inhibition zones formed around the wells. 


\section{Results and discussion}

\section{Spectroscopic analysis}

The FTIR spectra analysis shows similar curves for the three compounds. In the present paper, the infrared spectrum of (1) only is presented (Fig. 1). The most important absorption bands of the all compounds as well as their assignments are given in Table 1 . The broad band around $3400 \mathrm{~cm}^{-1}$ in the spectrum can be attributed to stretching vibrations of water molecule. The nitrate vibration bands are observed around $800 \mathrm{~cm}^{-1}\left(v_{2}\right)$ and $700 \mathrm{~cm}^{-1}\left(v_{4}\right)[53,54]$ as well as a very intense band located near 1300 $\mathrm{cm}^{-1}\left(v_{3}\right)$ indicating the presence of free $\mathrm{NO}_{3}{ }^{-}$groups [55]. Concerning the organic molecule, the two bands situated closed to 3000 and $1580 \mathrm{~cm}^{-1}$ can be assigned to the stretching and bending vibration modes of $\mathrm{NH}_{2}{ }^{+}$, respectively [56]. The asymmetric and symmetric stretching vibration modes of methyl groups are represented by two near bands located around 2800 and $2760 \mathrm{~cm}^{-1}$ which can be assigned to the asymmetric and symmetric vibration modes respectively $[57,58]$. A number of bands appearing in the spectral region of low wave number $\left(500-600 \mathrm{~cm}^{-1}\right)$ are attributed to the different vibration modes of the organic ring.

\section{Crystal structures}

All the crystal data and structure refinement details are listed in Table 2. Selected bond distances and angles as well as hydrogen bond geometry are given in tables 3 and 4 respectively. All of the studied hybrid nitrates crystallize isotypically in the triclinic system, centrosymmetric space group Pī. For this reason, only figures relative to the manganese based compound are shown. Figure 2 represents the asymmetric unit extended by symmetry while the figures of the asymmetric units relative to the two other materials are given in SI1 and SI2. Figure 3 and Figure 4 show projections of the crystal structure of (1) along a and b-axes, respectively. Figure 2, representing the asymmetric unit extended by symmetry (Symmetry codes :(i): $-\mathrm{x}+1,-\mathrm{y}+1,-\mathrm{z}+1$; (ii) $-\mathrm{x}+3,-\mathrm{y},-\mathrm{z}+1$ ), shows that the molecular structures of the complexes consist of the divalent metallic cation surrounded by six water molecules in an octahedral 
fashion forming cationic entities $\left[\mathrm{M}^{\mathrm{II}}\left(\mathrm{H}_{2} \mathrm{O}\right)_{6}\right]^{2+}$, four free nitrate anions $\mathrm{NO}_{3}{ }^{-}$and isolated piperazine molecules $\left(\mathrm{C}_{4} \mathrm{H}_{12} \mathrm{~N}_{2}\right)^{2+}$. The metallic cations $\mathrm{M}^{2+}(1 / 2,1 / 2,1 / 2)$ occupy a special position coinciding with an inversion center so that, among the six water molecules forming the metallic octahedron, three water molecules (OW1, OW2 and OW3) are crystallographically independent. The piperazine molecules, with a chair conformation, are doubly protonated. The ring centroid of one of them (completed by symmetry) lies on inversion center while the centroid of the other is placed in a general position. As it can be seen in figure, $\mathrm{N}-\mathrm{H} \cdots \mathrm{O}$ and $\mathrm{OW}-\mathrm{H} \cdots \mathrm{O}$ relate the different entities to create an extensive $\mathrm{H}$-bond system being the origin of the 3D supramolecular structures. The two nitrogen centers in the piperazinediium cations are protonated. The $\mathrm{C}-\mathrm{C}$ distances take the values of 1.507 (2) and $1.518(2) \AA$ while the $\mathrm{C}-\mathrm{N}$ distances are in the range 1.482 (2)-1.497 (2) $\AA$. The angles $\mathrm{C}-\mathrm{C}-\mathrm{N}$ and $\mathrm{C}-\mathrm{N}-\mathrm{C}$ are close to the ideal tetrahedral angle $109^{\circ}$ (see SI3). Referring to the literature, the values of the different distances and angles are in good agreement with those reported in numerous previous works containing piperazinediium cations incorporated in hybrid materials $[15,22,59,60]$. The angles within the uncoordinated nitrate anions vary from $116.86(17)$ to $122.7(3)^{\circ}$ (table 3). The $\mathrm{N}-\mathrm{O}$ distances are between 1.219 (2) and 1.285 (2) $\AA$. These value ranges are in accordance with many studied structures involving free nitrate groups [3337]. The environment around the metallic cations can be described as a slightly distorted octahedron: polyhedra distorsion values have been calculated to be equal to $310^{-4}, 7.210^{-3}$ and $210^{-4}$ for $\mathrm{Mn}, \mathrm{Cu}$ and Co compounds, respectively. These irregular octahedra, situated in the center of the cells (Fig. 3) are separated by intermetallic distances $\mathrm{M}^{\mathrm{II}} \ldots \mathrm{M}^{\mathrm{II}}$ equal to 7.1795 (6), 7.2389 (6) and 7.1379 (4) $\AA$ for compounds (1), (2) and (3), respectively according to the crystallographic a-axis.

The deviation from the ideal octahedral geometry is revealed by the range of angles observed around the metallic center (from 86.97 (5) to 90.17 (6) ${ }^{\circ}$ for (1), from 87.15 (5) to 93.81 (5) ${ }^{\circ}$ for (2) and 86.84 (7) to $91.74(7){ }^{\circ}$ for $(3)$ ), while the interaxial angles $\mathrm{OW}-\mathrm{M}^{\mathrm{II}}-\mathrm{OW}^{\mathrm{i}}$ are equal to $180^{\circ}$ (table 3 ). The $\mathrm{Mn}-\mathrm{OW}$ and $\mathrm{Co}-\mathrm{OW}$ bond distances vary in the ranges 2.1382 (14)-2.2206 (13) and 2.0609 (18)2.1257 (18) E, respectively. Concerning the $\mathrm{Cu}$ based compound, the distorted octahedral arrangement 
around the metallic cation produce two equatorial bond distances of 1.9553 (12) and 2.0028 (12) $\AA$ which are very close and an axial one measuring 2.3554 (12) $\AA$ which is considerably longer. Therefore, $\mathrm{Cu}^{2+}$ cation displays the so-called [4+2] coordination type which is associated with the well-known Jahn-Teller effect $[16,20,61-63]$ and then the geometry around this metal can be described as square bipyramidal geometry. The third Figure shows that the metallic octahedra occupy the center of the cell. The piperazine cations are placed in the center of the faces formed by a and c-axes (position of the centroid: $(1 / 2,0,1 / 2)$ ) and on the edges parallel to the crystallographic b-axis. The free nitrate anions are inyolved in a hydrogen bond system formed by $\mathrm{OW}-\mathrm{H} \cdots \mathrm{O}$ and $\mathrm{N}-\mathrm{H} \cdots \mathrm{O}$ to generate the three dimensional structures. The oxygen atoms, which are acting as acceptors, are H-bonded to the oxygen atoms of the six water molecules surrounding the metallic cations and nitrogen atoms of the piperazine moieties. Indeed, the $\mathrm{OW}-\mathrm{H} \cdots \mathrm{O}$ created between the aqua molecules and the nitrate groups are considered as weak H-bonds $[64,65]$ except OW2 - O 7 for (1) (table 4). Within each structure and together with $\mathrm{N}-\mathrm{H} \cdots \mathrm{O}$ hydrogen bonds, these interactions are responsible of the 3D architecture which proves the important role of free nitrate anions in the supramolecular network. In addition, the nitrate ions are found to be stacked to form anionic layers parallel to the $\left(\begin{array}{lll}0 & 1 & 2\end{array}\right)$ plane. These layers alternate, along the crystallographic b-axis, with the cationic layers formed by the positively charged metallic octahedra and piperazine moieties (Fig. 3). $\left[\begin{array}{lll}2 & 0 & \overline{1}\end{array}\right]$ is a second direction of the anionic-cationic alternation established between the anionic and cationic layers parallel to the (1 $\left.\begin{array}{lll}0 & \overline{1}\end{array}\right)$ plane (Fig. 4). As seen in this figure, the cationic-cationic alternation between the protonated piperazine and the metallic octahedra is observed along the crystallographic b-axis.

\section{Thermal analysis}

Thermal analysis of $\left(\mathrm{C}_{4} \mathrm{H}_{12} \mathrm{~N}_{2}\right)_{3}\left[\mathrm{Mn}\left(\mathrm{H}_{2} \mathrm{O}\right)_{6}\right]\left(\mathrm{NO}_{3}\right)_{8}(\mathbf{1})$

The TG curve presented in Figure 5 (a) shows a small rise caused by a weight increase of $0.9 \%$ which indicates that the material incorporated half a water molecule (theoretical weight increase: $0.97 \%$ ) due to 


\section{ACCEPTED MANUSCRIPT}

the hygroscopic nature of the compound. The representation of the powder X-ray diffraction patterns TDXD (Fig. 6) shows that the resulting phase is crystalline.

The decomposition phenomenon begins with dehydration by the departure of 5 water molecules giving rise to an amorphous monohydrate phase (Fig. 6). The observed weight loss, $9.69 \%$, agrees closely with the expected value of $9.75 \%$. This step occurs within a large temperature range (until $200^{\circ} \mathrm{C}$ ). At the higher temperatures, the precursor is totally decomposed by losing, simultaneously, the remaining water molecules, the organic part and the nitrate anions. The two processes are inseparable under these conditions. The expected weight loss is $91.46 \%$ while the experimentally observed value is $91.05 \%$. Along the degradation, the intermediate phase is amorphous to X-rays. In fact, the TDXD plot shows no X-ray diffraction peaks between 200 and $400{ }^{\circ} \mathrm{C}$. In the end of the decomposition phenomenon of the manganese based complex, the final product is the manganese oxide $\mathrm{Mn}_{2} \mathrm{O}_{3}$. Based on the TDXD representation, this phase is crystallized and stable beyond $400^{\circ} \mathrm{C}$.

\section{Thermal analysis of $\left(\mathrm{C}_{4} \mathrm{H}_{12} \mathrm{~N}_{2}\right)_{3}\left[\mathrm{Cu}\left(\mathrm{H}_{2} \mathrm{O}\right)_{6}\right]\left(\mathrm{NO}_{3}\right)_{8}(2)$}

The copper based complex decomposes in two steps (Fig. 5 (b)). The first step corresponds to the dehydration. In fact, from 80 up to around $180^{\circ} \mathrm{C}$, five water molecules are eliminated from the crystal structure giving rise to a monohydrated phase. Through this step, there is formation of crystallized phases as shown in the TDXD representation (Fig. 7).

The dehydration occurs with a weight loss of $9.53 \%$ very close to the calculated value of $9.65 \%$. The next step is attributed to the total decomposition of the resulting phase. The total expected weight loss of $89.35 \%$ agrees well with the observed value of $90.38 \%$. The decomposition finished by the formation of the copper oxide $\mathrm{Cu}_{2} \mathrm{O}_{3}$ crystallized between 200 and $450{ }^{\circ} \mathrm{C}$ as it is clearly seen in the three-dimensional $\mathrm{X}$-ray diffraction pattern. This oxide is not stable and turns into a more stable crystalline phase which is the copper oxide $\mathrm{CuO}$. This transformation is proved by the apparition of new diffraction peak at around $450{ }^{\circ} \mathrm{C}\left(2 \theta=43^{\circ}\right)($ Fig. 7$)$. 
Thermal analysis of $\left(\mathrm{C}_{4} \mathrm{H}_{12} \mathrm{~N}_{2}\right)_{3}\left[\mathrm{Co}\left(\mathrm{H}_{2} \mathrm{O}\right)_{6}\right]\left(\mathrm{NO}_{3}\right)_{8}(3)$

Referring to the TG curve presented in Figure 5 (c), the initial behavior of compound (3) is slightly different compared to those observed for (1) and (2). Indeed, the precursor starts with a total dehydration phenomenon by evaporation of all the six water molecules present within the unit cell around the metallic cation (observed mass loss $11.91 \%$, calculated mass loss $11.7 \%$ ). This phenomenon takes place until around $180{ }^{\circ} \mathrm{C}$ and gives rise to the anhydrous phase $\left(\mathrm{C}_{4} \mathrm{H}_{12} \mathrm{~N}_{2}\right)_{3} \mathrm{Co}\left(\mathrm{NO}_{3}\right)_{8}$ which totally decomposes, in a next step, to end with the cobalt oxide $\mathrm{Co}_{2} \mathrm{O}_{3}$. The observed mass loss during this decomposition is 90.87 $\%$ while the theoretical one is $91.05 \%$.

It is interesting to note that the thermal decomposition phenomenon of the nitrate anion and formation of the metal oxide may be initiated through breaking of the $\mathrm{N}-\mathrm{O}$ bond in $\mathrm{M}-\mathrm{O}-\mathrm{NO}_{2}$ followed by departure of gaseous $\mathrm{NO}_{2}$.

\section{NCI analysis}

NCI calculations were carried out on the title compounds because they have nearly identical compositions and connectivity architecture only differing by the nature of the metallic cation. The purpose is the direct observation of ionic attractions and repulsions, hydrogen bonding and van der Waals attractions in these compounds to determine the main forces that govern their formation. Figure 8 shows the NCI domains around the metal complex in the Mn crystal. The plots for the other compounds are very similar, and are not shown for simplicity. The most important feature in these plots is the extended three-dimensional hydrogen bond network formed between the aqua ligands and the adjacent nitrate molecules. These hydrogen bonds are revealed in the NCI plot as round dotted domains. To further examine the noncovalent interactions as a whole, plots of the reduced density gradient (RDG) against the electron density multiplied by the second eigenvalue of the density Hessian are used. In previous works, it has been found that the separation between the attractive and repulsive interactions depend on the sign of the second eigenvalue, $\lambda_{2}$, of the electron-density Hessian where the positive $\left(\lambda_{2}>0\right)$ and negative $\left(\lambda_{2}<0\right)$ signs 
correspond to the repulsive and attractive regions, respectively [49]. Figure 9 represents the NCI analysis of the low and moderate density attractions relative to the three compounds based on $\mathrm{Mn}(\mathrm{a}), \mathrm{Cu}(\mathrm{b})$ and Co (c) respectively. The peaks at low RDG in the negative $\mathrm{x}$-axis $\left(\lambda_{2}<0\right)$ correspond to intermolecular attractive contacts, and can be grouped, as indicated in the plots, in three categories: $\mathrm{N}-\mathrm{H} \cdots \mathrm{O}$ and $\mathrm{OW}-\mathrm{H} \cdots \mathrm{O}$ hydrogen bonds, weak directional interactions between piperazine and water ligands and weak non-specific interactions (van der Waals). Clearly, the hydrogen bonds sustain the threedimensional structure of the crystal. Interestingly, the strength of the hydrogen bonds, which can be estimated by the electron density of the peaks, differs only slightly depending on the metal atoms as shown in Figure 9. Despite to isotype structures, this may be due to the variation of the atomic radius values of the metallic cations in their six fold coordination state [66].

\section{Biological study}

The antibacterial and antifungal tests were performed against five Gram-positive, three Gram-negative bacteria and three fungi at different concentrations of the three synthesized compounds. In preliminary screening, it has been found that the inhibition zones become larger when the concentrations of the compounds increase. This relation is generally observed in this type of tests $[67,68]$. Probably, this is due to the effect of the metal ions. For this reason, the results founded for the concentration of $150 \mathrm{mg} / \mathrm{mL}$ were used to discuss the biological activity of the three hybrid materials. The three present compounds were effective against the tested bacteria with variable ranges of diameters of inhibitory zones (Fig. 10). The cobalt based complex showed the highest activity. In fact, it presented very large inhibitory zones with different diameters varying from 30 to $43 \mathrm{~mm}$. Referring to the literature, the organometallic complexes based on Co are founded to be very effective against bacteria $[68,69]$. This can be due to the high toxicity of the divalent cobalt metal against these species. The Mn based compound presented moderate activity against three Gram-positive and only one Gram-negative bacteria. This can be due to the differences in cell wall structure of the bacteria which can produce differences in antibacterial susceptibility. In fact, Gram-positive bacteria possess a thick cell wall containing many active layers but 
in contrast, Gram negative bacteria have a relatively thin cell wall consisting of a few active layers [70]. Concerning the antifungal activity, it was observed that the Mn based compound had no activity against the tested fungi while the two others were effective. The Co (II) complex is found to be more fungi toxic than the $\mathrm{Cu}$ (II) based one with diameters of the inhibition zones ranging from 15 to $22 \mathrm{~mm}$ and from 20 to $30 \mathrm{~mm}$ respectively for compound (2) and (3). Based on these results, the antimicrobial activity of the investigated hybrid compounds follows the order: $\mathrm{Co}$ (II) $>\mathrm{Cu}$ (II) $>\mathrm{Mn}$ (II).

The separated fragments which are the piperazine and all metal nitrates were tested towards the same bacteria and fungi. All the results are regrouped in table 5. In fact, the tested standards exhibit very lower antibacterial activity as compared to the corresponding hybrid materials. The piperazine is found to be ineffective against the majority of the used bacteria. The manganese nitrate is the less active compound where the cobalt nitrate presents the highest antibacterial activity. Thus, the same order observed for the hybrid materials is followed by the metal nitrates. Concerning the antifungal activity, all the same tested standards are ineffective against the used fungi. The obtained results evidently show that the activity of the separated components becomes more pronounced when they are regrouped together in a whole complex. Thus, the structure and the assembly manner of these groups seem to be a major factor influencing the biological activity.

\section{Conclusion}

In summary, a new family of hybrid nitrate compounds has been prepared. Three new compounds based on $\mathrm{Mn}$ (II), $\mathrm{Cu}$ (II) and $\mathrm{Co}$ (II) metals and containing in their structures free nitrate ions and protonated piperazine cations have been successfully synthesized and characterized. The X-ray diffraction analysis showed that the materials are isotypically crystallized with a similar arrangement of different cationic and anionic entities in the space directions. A 3D hydrogen bonded system constructed by cationic (piperazine- $\left.-\mathrm{H}_{2}\right)^{2+}$ and $\left[\mathrm{M}^{\mathrm{II}}\left(\mathrm{H}_{2} \mathrm{O}\right)_{6}\right]^{2+}$ entities as donors and nitrate anions as acceptors has been established. The thermogravimetric analysis of the three complexes showed that their degradation proceeds in two steps: a dehydration followed by a total decomposition leading to the formation of the metal oxides $\mathrm{M}_{2} \mathrm{O}_{3}$. The degradation steps and their associated temperatures were comparative from one complex to another due to the close geometry as well as the similar covalent and non-covalent bonds 
existing within each one. The non-covalent interaction (NCI) plots using the calculated electron densities from density-functional calculations at the experimental crystal geometries were used to characterize the interactions in the crystal. The three-dimensional network is supported by hydrogen bonds between the metal complex and the nitrate anions. These hydrogen bonds show very slight differences depending on the metal center. Biologically, the three synthesized hybrid compounds were active against the tested bacteria and fungi with a highest potential showed by the cobalt based compound.

\section{Supplementary data}

CCDC Numbers: 1447621,1433261 and 1433259 contain the supplementary crystallographic data respectively for $\mathrm{Mn}, \mathrm{Cu}$ and $\mathrm{Co}$ compounds. These data can be obtained free of charge from the Cambridge Crystallographic data centre, 12 Union Road, Cambridge CB2 1EZ, UK. E-mail: deposit@ccdc.cam.uc.uk.

\section{Acknowledgements}

AOR thanks the Spanish Malta/Consolider initiative (no. CSD2007-00045).

\section{Formatting and funding sources}

This research did not receive any specific grand from funding agencies in the public, commercial or notfor-profit sectors.

\section{Conflicts of interest}

The authors declare no competing financial interest.

\section{References}

[1] E. C. Constable, Prog. Inorg. Chem. 42 (1994) 1637-1651

[2] K. A. Hirsch, S. R. Wilson and J. S. Moore, Inorg. Chem. 36 (1997) 2960-2968.

[3] K. R. Dunbar and K. R. Heintz, Prog. Inorg. Chem. (1996) 283-391. 
[4] O. M. Yaghi and H. Li, J. Am. Chem. Soc. 117 (1995) 10401-10402.

[5] O. M. Yaghi, H. Li and T. L. Groy, J. Am. Chem. Soc. 1118 (1996) 9096-9101.

[6] C. M. R. Juan and B. Lee, Coord. Chem. Rev. 183 (1999) 43-80.

[7] T. N. Guru Row, Coord. Chem. Rev. 183 (1999) 81-100.

[8] G. R. Desiraju, Acc. Chem. Res. 29 (1996) 441-449.

[9] S. S. Kuduva, D. C. Craig, A. Nangia and G. R. Desiraju, J. Am. Chem. Soc. 121 (1999) 1936-1944.

10] I. Unamuno, J. M. Gutiérrez-Zorrilla, A. Luque, P. Román, L. Lezama, R. Calvo and T. Rojo, Inorg. Chem. 37 (1998) 6452-6440.

[11] M.-C. Tse, K.-K. Cheung, M. C.-W. Chan and C.-M. Che, Chem. Commun. (1998) 2295-2296.

[12] D. S. Reddy, K. Panneerselvam, T. Pilati and G. R. Desiraju, J. Chem. Soc. Chem. Commun. (1993) 661-662.

[13] Y.-B. Dong, M. D. Smith, R. C. Layland and H.-C. zur Loye, Inorg. Chem. (1999) 38, 5027-5033.

[14] J.-M. Lehn, Supramolecular Chemistry. Concepts and Perspectives, VCH, Weinheim, 1995.

[15] W. Rekik, H. Naïli, T. Bataille, T. Roisnel and T. Mhiri, Inorg. Chim. Acta 359 (2006) 3954-3962.

[16] H. Naïli, W. Rekik, T. Bataille and T. Mhiri. Polyhedron 25 (2006) 3543-3554.

[17] W. Rekik, H. Naïli, T. Mhiri and T. Bataille, Acta Cryst. E65 (2009) 1404-1405.

[18] W. Rekik, H. Naïli, T. Mhiri and T. Bataille, Acta Cryst. E67 (2011) 1176-1177.

[19] D. Ben Hassan, W. Rekik, H. Naïli and T. Mhiri, Chem. Pap. 68 (2) (2014) 210-216.

[20] N. Loulou Nkhili, W. Rekik, T. Mhiri, K. T. Mahmudov, M. N. Kopylovich and H. Naïli, Inorg. Chim. Acta 412 (2014) 27-31.

[21] O. Kammoun, N. Loulou Nkhili, W. Rekik, H. Naïli, T. Mhiri and T. Bataille, Chem. Crystallogr. 42 (2012) 103-110.

[22] N. Loulou Nkhili, W. Rekik, H. Naïli, T. Mhiri and T. Bataille, Solid State Phenom. 194 (2013) 171174.

[23] D. A. Beauchamp and S. J. Loeb, Chem. Eur. J. 8(22) (2002) 5084-5088. 
[24] H. Keypour, P. Arzhangi, N. Rahpeyma, M. Rezaeivala, Y. Elerman, H. Reza KhavasiInorganica, Inorg. Chim. Acta 367 (2011) 9-14.

[25] H. Keypour, N. Rahpeyma, P. Arzhangi, M. Rezaeivala, Y. Elerman, O. Buyukgungor and L. Valencia, Polyhedron 29 (2010) 1144-1148.

[26] C. R. Bondy, P. A. Gale and S. J. Loeb, Supramol. Chem. 2 (2002) 93-96.

[27] U. Suksangpanya, A. J. Blake, P. Hubberstey, D. J. Parker, S. J. Teat and C. Wilsona, Cryst. Eng. Comm. 5(4) (2003) 23-33.

[28] C. Rotger, B. Soberats, D. Quiñonero, A. Frontera, P. Ballester, J. Benet-Buchholz, P. M. Deyà, and A. Costa, Eur. J. Org. Chem. (11) (2008) 1864-1868

[29] F. Hueso-Ureña, S. B. Jiménez-Pulido, M. N. Moreno-Carretero, M. Quirós-Olozábal and J. M. Salas-Peregrin, Polyhedron 16(4) (1997) 607-612.

[30] A. Mustapha, P. Duckmanton, J. Reglinski, A. R. Kennedy, Polyhedron 29 (2010) 2590-2594.

[31] S. Kumar Padhi, V. Manivannan, Polyhedron 26 (2007) 1619-1624.

[32] M. Tyagi, S. Chandra, P. Tyagi, Spectrochim. Acta Part A117 (2014) 1-8.

[33] I. Turel, N. Bukovec, M. Goodgame and D. J. Williams, Polyhedron 16 (1997) 1701-1706.

[34] D. Wu, Y. Zhao, H. Ye and G. Wu, Acta Cryst. E66 (2010) 1568-1569.

[35] G.-Q. Guo, J.-H. Deng and J. Chen, Acta Cryst. E66 (2010) 1415-16.

[36] T. Rosu, E. Pahontu, M. Reka-Stefana, D.-C. Ilies, R. Georgescu, S. Shova, A. Gulea, Polyhedron 31 (2012) 352-360.

[37] S. Ilhan, H. Temel, J. Mol. Struct. 891 (2008) 157-166.

[38] W.-T. Deng, J.-C. Liu, J. Cao, Inorg. Chem. Commun. 35 (2013) 315-317.

[39] C.-Q. Liu, J.-M. Shi and C.-J. Wu, Z. Kristallogr. NCS. 218 (2003) 297-298.

[40] Z. Glasovaca, V. Štrukil, M. Eckert-Maksić, D. Schröder, M. Schlangenc and H. Schwarz, Int. J. Mass Spectrom. 290 (2010) 22-31.

[41] Bruker-Nonius. SAINT version 7.23A. Bruker AXS Inc. Madison, W., USA, (2005). 
[42] G. M. Sheldrick, SADABS Bruker AXS Inc., Madison, Wisconsin, USA, (2002).

[43] A. Altomare, M. C. Burla, M. Camalli, G. Cascarano, C. Giacovazzo, A. Guagliardi, A. G. G.

Moliterni, G. Polidori and R. Spagna, J. Appl. Cryst. 32 (1999) 115-119.

[44] G. M. Sheldrick, Acta Cryst. C71 (2015) 3-8.

[45] L. J. Farrugia, J App. Crystallogr. 32 (1999) 837-838.

[46] P. Giannozzi, et al., J. Phys. Condens. Matter. 21 (2009) 395-502.

[47] J. P. Perdew, K. Burke and M. Ernzerhof, Phys. Rev. Lett. 77 (1996) 3865-3868.

[48] N. Marzari, D. Vanderbilt, A. de Vita, M. C. Payne, Phys. Rev. Lett. 82 (1999) 3296-3299.

[49] E. R. Johnson, S. Keinan, P. Mori-Sanchez, J. Contreras-García, A. J. Cohen, W. J. Yang, Am. Chem. Soc. 132 (2010) 6498-6506.

[50] A. Otero-de-la Roza, E. R.Johnson, J. Contreras-Garcia, Phys. Chem. Chem. Phys. 14 (2012) 1216512172.

[51] A. Otero-de-la Roza, M.A. Blanco, A. MartÃn PendÃ, V. LuaÃ, Comput. Phys. Commun. 180 (2009) 157-166.

[52] A. Otero-de-la Roza, E.R. Johnson, V. LuaÃ, Comput. Phys. Commun. 185 (2014) 1007-1018.

[53] H. Temel, S. Ilhan, M. Sekerci, R. Ziyadanogulları, Spectrosc. Lett. 35(2) (2002) 219-228.

[54] S. Ilhan, H. Temel, A. Kılıc, E. Tas, Transition Met. Chem. 32 (2007) 1012-1017.

[55] K. Nakamoto, Infrared Raman Spectra Inorg. Coord. Compd, Part B, fifth ed., Wiley, New York, 2009.

[56] C.R. Saha, J. Inorg. Nucl. Chem. 38 (1976) 1635-1640.

[57] N. Prabavathi, A. Nilufer and V. Krishnakumar, Spectrochim. Acta Part A 121 (2014) 483-439.

[58] E. Tasal, M. Kumalar, Spectrochim. Acta 96 (2012) 548-562.

[59] W. Rekik, H. Naïli, T. Mhiri and T. Bataille, Acta Cryst. E61 (2005) 629-631.

[60] J.-X. Pan, G.-Y. Yang, Y.-Q. Sun, Acta Cryst. E59 (2003) 286-288. 
[61] N. Loulou Nkhili, W. Rekik, H. Naïli, T. Mhiri and T. Bataille, J. Chem. Crystallogr. 41 (2011) $1680-1687$.

[62] V. Petrusevski, Bull. Chem. Technol. Macedonia. 9 (1990) 13-19.

[63] W. Zhang, L. Chen, R. Xiong, T. Nakamura, S.D. Huang, J. Am. Chem. Soc. 13 (2009) 1254412545.

[64] I. D. Brown, Acta Cryst. A32 (1976) 24-31.

[65] R. H. Blessing, Acta Cryst. B42 (1986) 613-621.

[66] R.D. Shannon and C.T. Prewitt. Acta Cryst. B25 (1969) 925-964.

[67] M. B. Fugu, N. P. Ndahi, B. B. Paul and A. N. Mustapha. J. Chem. Pharm. Res. 5(4) (2013) 22-28.

[68] V. A. Shelke, S.M. Jadhav, S.G. Shankarwar, A.S. Munde and T.K. Chondhekar, Bull. Chem. Soc. Ethiop. 25(3) (2011) 381-391.

[69] A. Chandra Pandey, R. Kothari and B. Sharma, J. Environ. Res. Dev. 6(1) (2011) 51-56.

[70] A. L. Koch, Clin. Microbiol. Rev. 16 (2003) 673-687. 


\section{Tables}

Table 1: Characteristic IR absorption bands $\left(\mathrm{cm}^{-1}\right)$ of (1), (2) and (3)

\begin{tabular}{llll}
\hline Band assignment & Compound (1) & Compound (2) & Compound (3) \\
\hline$v(\mathrm{O}-\mathrm{H})$ & 3355 & 3344 & 3367 \\
$v\left(\mathrm{NH}_{2}\right)$ & 3026 & 3029 & 3084 \\
$v_{\text {asy }}\left(\mathrm{CH}_{2}\right)$ & 2833 & 2835 & 2884 \\
$v_{\text {sy }}\left(\mathrm{CH}_{2}\right)$ & 2768 & 2773 & 2790 \\
$\delta\left(\mathrm{NH}_{2}\right)$ & 1587 & 1587 & 1594 \\
$v_{2}\left(\mathrm{NO}_{3}\right)$ & 806 & 812 & 815 \\
$v_{3}\left(\mathrm{NO}_{3}\right)$ & 1323 & 1324 & 1316 \\
$v_{4}\left(\mathrm{NO}_{3}\right)$ & 700 & 714 & 707 \\
organic ring & $1100-850$ & $1100-850$ & $1100-850$ \\
\hline
\end{tabular}


Table 2: Crystal data and structure refinement details of (1), (2) and (3)

\begin{tabular}{|c|c|c|c|}
\hline & $\left(\mathrm{C}_{4} \mathrm{H}_{12} \mathrm{~N}_{2}\right)_{3}\left[\mathrm{Mn}\left(\mathrm{H}_{2} \mathrm{O}\right)_{6}\right]\left(\mathrm{NO}_{3}\right)_{8}(\mathbf{1})$ & $\left(\mathrm{C}_{4} \mathrm{H}_{12} \mathrm{~N}_{2}\right)_{3}\left[\mathrm{Cu}\left(\mathrm{H}_{2} \mathrm{O}\right)_{6}\right]\left(\mathrm{NO}_{3}\right)_{8}(2)$ & $\left(\mathrm{C}_{4} \mathrm{H}_{12} \mathrm{~N}_{2}\right)_{3}\left[\mathrm{Co}\left(\mathrm{H}_{2} \mathrm{O}\right)_{6}\right]\left(\mathrm{NO}_{3}\right)_{8}(\mathbf{3})$ \\
\hline Formula weight $(\mathrm{g} / \mathrm{mol})$ & 923.58 & 932.18 & 927.57 \\
\hline Crystal system & triclinic & triclinic & triclinic \\
\hline Space group & $\mathrm{P} \overline{1}$ & $\mathrm{P}_{\overline{1}}$ & Pī \\
\hline $\mathrm{a}(\AA)$ & $7.1795(6)$ & $7.2389(6)$ & $7.1379(4)$ \\
\hline b (Å) & $11.4409(10)$ & $11.3029(9)$ & $11.3792(7)$ \\
\hline c $(\AA)$ & $12.3393(12)$ & $12.1480(11)$ & $12.2666(7)$ \\
\hline$\alpha\left({ }^{\circ}\right)$ & $65.286(5)$ & $66.600(4)$ & $65.600(2)$ \\
\hline$\beta\left(^{\circ}\right)$ & $89.186(5)$ & $88.975(4)$ & $89.136(2)$ \\
\hline$\gamma\left(0^{\circ}\right)$ & $84.975(5)$ & $85.344(4)$ & $84.853(2)$ \\
\hline Volume $\left(\AA^{3}\right)$ & $916.89(15)$ & $909.09(14)$ & $903.42(9)$ \\
\hline $\mathrm{Z}$ & 1 & 1 & 1 \\
\hline Color/Shape & Colorless / block & Blue / block & Pink / block \\
\hline$\lambda\left(\mathrm{K}_{\alpha}(\mathrm{Mo})\right)(\hat{\AA})$ & 0.71073 & 0.71073 & 0.71073 \\
\hline$\mu_{\text {exp }}\left(\mathrm{mm}^{-1}\right)$ & 0.484 & 0.726 & 0.601 \\
\hline Absorption correction & Multi-scan & Multi-scan & Multi-scan \\
\hline Min. and max. transmission & $0.816,0.948$ & $0.797,0.910$ & $0.821,0.908$ \\
\hline Number of parameters & 283 & 295 & 295 \\
\hline Independent reflections & 6724 & 4092 & 4033 \\
\hline Reflections with $\mathrm{I}>2 \sigma(\mathrm{I})$ & 5033 & 3650 & 3543 \\
\hline$\theta$ range $\left(^{\circ}\right)$ & $2.85-30.56$ & $2.82-27.18$ & $3.194-27.484$ \\
\hline \multirow[t]{3}{*}{ Index ranges } & $-10 \leq \mathrm{h} \leq 10$ & $-9 \leq \mathrm{h} \leq 9$ & $-9 \leq \mathrm{h} \leq 9$ \\
\hline & $-17 \leq \mathrm{k} \leq 17$ & $-14 \leq \mathrm{k} \leq 14$ & $-14 \leq \mathrm{k} \leq 14$ \\
\hline & $-18 \leq 1 \leq 18$ & $-14 \leq 1 \leq 15$ & $-15 \leq 1 \leq 15$ \\
\hline Rint & 0.0365 & 0.0354 & 0.0310 \\
\hline $\mathrm{R}_{1}$ & 0.0705 & 0.0368 & 0.0525 \\
\hline $\mathrm{wR}_{2}$ & 0.1551 & 0.1050 & 0.1531 \\
\hline$\Delta \rho \min / \max$ & $-0.480 / 1.277$ & $-0.317 / 0.324$ & $-0.364 / 0.906$ \\
\hline
\end{tabular}


Table 3: Selected bond distances $(\AA)$ and angles $\left({ }^{\circ}\right)$ within the metallic octahedra and the nitrate anions for compounds (1), (2) and (3)

\begin{tabular}{|c|c|c|c|}
\hline & Compound (1) & Compound (2) & Compound (3) \\
\hline \multicolumn{4}{|l|}{ Metallic octahedron } \\
\hline $\mathrm{M}-\mathrm{OW} 1$ & $2.2206(13)$ & $2.3554(12)$ & $2.1257(18)$ \\
\hline $\mathrm{M}-\mathrm{OW} 2$ & $2.1382(14)$ & $1.9553(12)$ & $2.0609(18)$ \\
\hline $\mathrm{M}-\mathrm{OW} 3$ & $2.1968(13)$ & $2.0028(12)$ & $2.0930(17)$ \\
\hline $\mathrm{OW} 1-\mathrm{M}-\mathrm{OW} 2$ & $90.17(6)$ & $93.81(5)$ & $91.74(7)$ \\
\hline $\mathrm{OW} 1-\mathrm{M}-\mathrm{OW} 3$ & $86.99(6)$ & $87.15(5)$ & $86.84(7)$ \\
\hline $\mathrm{OW} 2-\mathrm{M}-\mathrm{OW} 3$ & $87.97(5)$ & $92.92(7)$ & $88.37(7)$ \\
\hline $\mathrm{OW} 1-\mathrm{M}-\mathrm{OW} 1^{\mathrm{i}}$ & 180.0 & 180.0 & 180.0 \\
\hline $\mathrm{OW} 2-\mathrm{M}-\mathrm{OW} 2^{\mathrm{i}}$ & 180.0 & $180.00(7)$ & 180.0 \\
\hline $\mathrm{OW} 3-\mathrm{M}-\mathrm{OW} 3^{\mathrm{i}}$ & $180.00(6)$ & $180.00(7)$ & 180.0 \\
\hline \multicolumn{4}{|l|}{ Nitrate groups } \\
\hline $\mathrm{N} 1-\mathrm{O} 1$ & $1.2556(19)$ & $1.2572(18)$ & $1.255(3)$ \\
\hline $\mathrm{N} 1-\mathrm{O} 2$ & $1.2522(19)$ & $1.2568(18)$ & $1.252(3)$ \\
\hline $\mathrm{N} 1-\mathrm{O} 3$ & $1.2518(18)$ & $1.2428(18)$ & $1.246(3)$ \\
\hline $\mathrm{N} 2-\mathrm{O} 4$ & $1.2296(19)$ & $1.2335(18)$ & $1.218(3)$ \\
\hline $\mathrm{N} 2-\mathrm{O} 5$ & 1.2709 (19) & 1.2567 (19) & $1.264(3)$ \\
\hline $\mathrm{N} 2-\mathrm{O} 6$ & $1.2565(19)$ & $1.2621(18)$ & $1.250(3)$ \\
\hline $\mathrm{N} 3-\mathrm{O} 7$ & $1.285(2)$ & $1.2777(18)$ & $1.277(3)$ \\
\hline $\mathrm{N} 3-\mathrm{O} 8$ & $1.219(2)$ & $1.2428(18)$ & $1.229(3)$ \\
\hline N3-O9 & $1.238(2)$ & $1.234(2)$ & $1.229(3)$ \\
\hline $\mathrm{N} 4-\mathrm{O} 10$ & $1.2738(18)$ & $1.2715(18)$ & $1.268(3)$ \\
\hline $\mathrm{N} 4-\mathrm{O} 11$ & 1.2585 (19) & $1.2623(18)$ & $1.257(3)$ \\
\hline $\mathrm{N} 4-\mathrm{O} 12$ & $1.2381(17)$ & $1.2316(17)$ & $1.235(3)$ \\
\hline $\mathrm{O} 1-\mathrm{N} 1-\mathrm{O} 2$ & $118.68(13)$ & $118.43(13)$ & $118.26(19)$ \\
\hline $\mathrm{O} 1-\mathrm{N} 1-\mathrm{O} 3$ & $119.53(15)$ & $120.09(14)$ & $119.9(2)$ \\
\hline $\mathrm{O} 2-\mathrm{N} 1-\mathrm{O} 3$ & $121.78(16)$ & $121.48(14)$ & $121.8(2)$ \\
\hline $\mathrm{O} 4-\mathrm{N} 2-\mathrm{O} 5$ & $121.12(16)$ & $121.78(15)$ & $121.2(2)$ \\
\hline $\mathrm{O} 4-\mathrm{N} 2-\mathrm{O} 6$ & 121.47 (16) & $120.57(15)$ & $121.4(2)$ \\
\hline $\mathrm{O} 5-\mathrm{N} 2-\mathrm{O} 6$ & $117.40(14)$ & $117.65(14)$ & $117.4(2)$ \\
\hline $\mathrm{O} 7-\mathrm{N} 3-\mathrm{O} 8$ & $119.90(19)$ & $119.56(15)$ & $119.7(2)$ \\
\hline $\mathrm{O} 7-\mathrm{N} 3-\mathrm{O} 9$ & $116.86(17)$ & $118.62(14)$ & $117.6(2)$ \\
\hline $\mathrm{O} 8-\mathrm{N} 3-\mathrm{O} 9$ & $123.2(2)$ & $121.80(15)$ & $122.7(3)$ \\
\hline $\mathrm{O} 10-\mathrm{N} 4-\mathrm{O} 11$ & $118.40(13)$ & 118.07 (13) & $118.38(18)$ \\
\hline $\mathrm{O} 10-\mathrm{N} 4-\mathrm{O} 12$ & $120.47(14)$ & $120.98(14)$ & $120.7(2)$ \\
\hline $\mathrm{O} 11-\mathrm{N} 4-\mathrm{O} 12$ & $121.13(14)$ & 120.95 (14) & $120.94(19)$ \\
\hline
\end{tabular}


Table 4: Hydrogen bond geometry $\left(\AA,^{\circ}\right)$
D...A
D-H...A

$\left(\mathrm{C}_{4} \mathrm{H}_{12} \mathrm{~N}_{2}\right)_{3}\left[\mathrm{Mn}\left(\mathrm{H}_{2} \mathrm{O}\right)_{6}\right]\left(\mathrm{NO}_{3}\right)_{8}$

\begin{tabular}{|c|c|c|}
\hline OW1-HW1A $\cdots \mathrm{O}^{\mathrm{iii}}$ & $2.886(2)$ & $170(3)$ \\
\hline 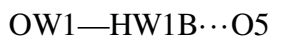 & $2.7345(19)$ & $175(3)$ \\
\hline $\mathrm{OW} 2-\mathrm{HW} 2 \mathrm{~A} \cdots \mathrm{O}^{\mathrm{iv}}$ & $2.8752(19)$ & $167(3)$ \\
\hline OW2-HW2B $\cdots \mathrm{O} 7$ & $2.691(2)$ & $165(3)$ \\
\hline OW3-HW3A $\cdots$ O10 & 2.7667 (19) & $175(3)$ \\
\hline OW3-HW3B $\cdots$ O $^{\mathrm{iii}}$ & $2.792(2)$ & $165(3)$ \\
\hline $\mathrm{N} 5-\mathrm{HN} 5 \mathrm{~A} \cdots \mathrm{O} 11$ & $2.843(2)$ & $160(2)$ \\
\hline $\mathrm{N} 5-\mathrm{HN} 5 \mathrm{~B} \cdots \mathrm{O} 2^{\mathrm{v}}$ & $2.927(2)$ & $161(2)$ \\
\hline N6-HN6A $\cdots$ O10 $0^{\mathrm{vi}}$ & $2.8326(19)$ & $159(2)$ \\
\hline N6-HN6B $\cdots O 1^{\mathrm{vii}}$ & 2.8319 (19) & $156(2)$ \\
\hline N7-HN7A $\cdots O 8^{\text {viii }}$ & $2.785(2)$ & $137(2)$ \\
\hline N7-HN7B $\cdots$ O6 & $2.866(2)$ & $158(2)$ \\
\hline
\end{tabular}

$\left(\mathrm{C}_{4} \mathrm{H}_{12} \mathrm{~N}_{2}\right)_{3}\left[\mathrm{Cu}\left(\mathrm{H}_{2} \mathrm{O}\right)_{6}\right]\left(\mathrm{NO}_{3}\right)_{8}(2)$

\begin{tabular}{|c|c|c|}
\hline OW1-HW1A $\cdots \mathrm{O}^{\mathrm{iii}}$ & $2.9205(18)$ & $164(3)$ \\
\hline 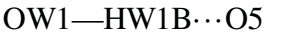 & $2.7375(18)$ & $175(3)$ \\
\hline $\mathrm{OW} 2-\mathrm{HW} 2 \mathrm{~A} \cdots \mathrm{O}^{\mathrm{iv}}$ & $2.7800(17)$ & $157(3)$ \\
\hline OW2-HW2B $\cdots \mathrm{O} 7$ & $2.7090(18)$ & $173(3)$ \\
\hline OW3-HW3A $\cdots \mathrm{O} 10$ & $2.7728(18)$ & $178(3)$ \\
\hline OW3-HW3B $\cdots \mathrm{O}^{\mathrm{iii}}$ & $2.8244(17)$ & $172(3)$ \\
\hline 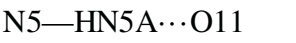 & $2.8109(19)$ & $157.2(18)$ \\
\hline $\mathrm{N} 5-\mathrm{HN} 5 \mathrm{~B} \cdots \mathrm{O} 2^{\mathrm{v}}$ & $2.911(2)$ & $160(2)$ \\
\hline N6-HN6A $\cdots$ O10 ${ }^{\mathrm{vi}}$ & $2.8569(19)$ & $157.0(18)$ \\
\hline $\mathrm{N} 6-\mathrm{HN} 6 \mathrm{~B} \cdots \mathrm{O} 1^{\mathrm{v}}$ & $2.8160(18)$ & $155.4(18)$ \\
\hline N7-HN7A $\cdots \mathrm{O}^{\mathrm{vii}}$ & $2.8373(19)$ & $146.9(19)$ \\
\hline N7-HN7B $\cdots \mathrm{O} 6$ & $2.842(2)$ & $170(2)$ \\
\hline
\end{tabular}

$\left(\mathrm{C}_{4} \mathrm{H}_{12} \mathrm{~N}_{2}\right)_{3}\left[\mathrm{Co}\left(\mathrm{H}_{2} \mathrm{O}\right)_{6}\right]\left(\mathrm{NO}_{3}\right)_{8}$

\begin{tabular}{|c|c|c|}
\hline OW1-HW1A $\cdots 3^{\text {iii }}$ & $2.897(3)$ & $165(4)$ \\
\hline 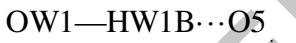 & $2.727(3)$ & $170(4)$ \\
\hline $\mathrm{OW} 2-\mathrm{HW} 2 \mathrm{~A} \cdots \mathrm{O}^{\mathrm{iv}}$ & $2.936(3)$ & $166(4)$ \\
\hline $\mathrm{OW} 2-\mathrm{HW} 2 \mathrm{~B} \cdots \mathrm{O} 7$ & $2.691(3)$ & $178(4)$ \\
\hline OW3-HW3A ‥ O10 & $2.770(2)$ & $173(4)$ \\
\hline OW3-HW3B $\cdots \mathrm{O}^{\mathrm{iii}}$ & $2.791(3)$ & 169 (4) \\
\hline N5-HN5A $\cdots \mathrm{O} 11$ & $2.827(3)$ & $156(3)$ \\
\hline $\mathrm{N} 5-\mathrm{HN} 5 \mathrm{~B} \cdots \mathrm{O} 2^{\mathrm{v}}$ & $2.915(3)$ & $162(3)$ \\
\hline $\mathrm{N} 6-\mathrm{HN} 6 \mathrm{~A} \cdots \mathrm{O} 10^{\mathrm{v}}$ & $2.831(3)$ & $158(3)$ \\
\hline N6-HN6B $\cdots O 1^{\text {ix }}$ & $2.820(3)$ & $159(3)$ \\
\hline N7-HN7A $\cdots O 8^{\text {vii }}$ & $2.793(3)$ & $142(3)$ \\
\hline N7-HN7B $\cdots \mathrm{O} 6$ & $2.859(3)$ & $157(3)$ \\
\hline
\end{tabular}


Table 5 : Diameters of inhibitory zones, measured in $\mathrm{mm}$ for aqueous solutions of the piperazine, manganese nitrate, copper nitrate and cobalt nitrate at the concentration of 150 $\mathrm{mg} / \mathrm{ml}$

\begin{tabular}{lllll}
\hline & Piperazine & Mn & $\mathrm{Cu}$ & Co \\
Bs & --- & 9 & 17 & 28 \\
Bc & --- & 7 & 15 & --- \\
Sa & --- & 6 & 19 & 21 \\
Lm & --- & --- & 16 & 19 \\
Ml & --- & --- & 20 & 25 \\
Se & --- & 4 & 14 & --- \\
Ec & 10 & 3 & --- & 21 \\
Kp & 8 & 7 & 20 & 31 \\
Fsp & --- & --- & --- & --- \\
Foxy & --- & --- & --- & --- \\
Psp & --- & --- & --- & --- \\
\hline
\end{tabular}




\section{Figure captions}

Figure 1: FTIR spectrum of $\left(\mathrm{C}_{4} \mathrm{H}_{12} \mathrm{~N}_{2}\right)_{3}\left[\mathrm{Mn}\left(\mathrm{H}_{2} \mathrm{O}\right)_{6}\right]\left(\mathrm{NO}_{3}\right)_{8}(\mathbf{1})$

Figure 2: Asymmetric unit of $\left(\mathrm{C}_{4} \mathrm{H}_{12} \mathrm{~N}_{2}\right)_{3}\left[\mathrm{Mn}\left(\mathrm{H}_{2} \mathrm{O}\right)_{6}\right]\left(\mathrm{NO}_{3}\right)_{8}(\mathbf{1})$ extended by symmetry to complete $\left(\mathrm{C}_{4} \mathrm{H}_{12} \mathrm{~N}_{2}\right)^{2+}$ and $\left[\mathrm{Mn}\left(\mathrm{H}_{2} \mathrm{O}\right)_{6}\right]^{2+}$ entities. The thermal ellipsoids are plotted at the 50\% probability level. $\mathrm{H}$ bonds are represented by dashed lines. (Symmetry codes: (i): $-\mathrm{x}+1,-$ $\mathrm{y}+1,-\mathrm{z}+1 ;($ ii) $-\mathrm{x}+3,-\mathrm{y},-\mathrm{z}+1)$

Figure 3: A projection of the structure of $\left(\mathrm{C}_{4} \mathrm{H}_{12} \mathrm{~N}_{2}\right)_{3}\left[\mathrm{Mn}\left(\mathrm{H}_{2} \mathrm{O}\right)_{6}\right]\left(\mathrm{NO}_{3}\right)_{8}$ (1) along the crystallographic a-axis. Hydrogen bonds are represented in dashed lines. Hydrogen atoms are omitted for clarity

Figure 4: $\mathrm{A}$ view of $3 \mathrm{D}$ packing in $\left(\mathrm{C}_{4} \mathrm{H}_{12} \mathrm{~N}_{2}\right)_{3}\left[\mathrm{Mn}\left(\mathrm{H}_{2} \mathrm{O}\right)_{6}\right]\left(\mathrm{NO}_{3}\right)_{8}(\mathbf{1})$ down the crystallographic b-axis showing the cationic-cationic alternation. All hydrogen atoms and bonds are omitted for the clarity of the figure

Figure 5: The TG curve representations of the thermal decomposition of

$\left(\mathrm{C}_{4} \mathrm{H}_{12} \mathrm{~N}_{2}\right)_{3}\left[\mathrm{Mn}\left(\mathrm{H}_{2} \mathrm{O}\right)_{6}\right]\left(\mathrm{NO}_{3}\right)_{8}(\mathbf{1})(\mathrm{a}),\left(\mathrm{C}_{4} \mathrm{H}_{12} \mathrm{~N}_{2}\right)_{3}\left[\mathrm{Cu}\left(\mathrm{H}_{2} \mathrm{O}\right)_{6}\right]\left(\mathrm{NO}_{3}\right)_{8}$ (2) (b) and

$\left(\mathrm{C}_{4} \mathrm{H}_{12} \mathrm{~N}_{2}\right)_{3}\left[\mathrm{Co}\left(\mathrm{H}_{2} \mathrm{O}\right)_{6}\right]\left(\mathrm{NO}_{3}\right)_{8}(3)$ (c)

Fig. 6: TDXD plot for the thermal decomposition of $\left(\mathrm{C}_{4} \mathrm{H}_{12} \mathrm{~N}_{2}\right)_{3}\left[\mathrm{Mn}\left(\mathrm{H}_{2} \mathrm{O}\right)_{6}\right]\left(\mathrm{NO}_{3}\right)_{8}(\mathbf{1})$

Figure 7: TDXD plot for the thermal decomposition of $\left(\mathrm{C}_{4} \mathrm{H}_{12} \mathrm{~N}_{2}\right)_{3}\left[\mathrm{Cu}\left(\mathrm{H}_{2} \mathrm{O}\right)_{6}\right]\left(\mathrm{NO}_{3}\right)_{8}(2)$

Figure 8: The NCI domains around the metal octahedron in the Mn crystal

Figure 9: NCI analysis showing the low and moderate density attractions in the compounds

$\left(\mathrm{C}_{4} \mathrm{H}_{12} \mathrm{~N}_{2}\right)_{3}\left[\mathrm{Mn}\left(\mathrm{H}_{2} \mathrm{O}\right)_{6}\right]\left(\mathrm{NO}_{3}\right)_{8}(\mathbf{1})(\mathrm{a}),\left(\mathrm{C}_{4} \mathrm{H}_{12} \mathrm{~N}_{2}\right)_{3}\left[\mathrm{Cu}\left(\mathrm{H}_{2} \mathrm{O}\right)_{6}\right]\left(\mathrm{NO}_{3}\right)_{8}$ (2) (b) and

$\left(\mathrm{C}_{4} \mathrm{H}_{12} \mathrm{~N}_{2}\right)_{3}\left[\mathrm{Co}\left(\mathrm{H}_{2} \mathrm{O}\right)_{6}\right]\left(\mathrm{NO}_{3}\right)_{8}(3)(\mathrm{c})$

Figure 10: Diameters of inhibitory zones, measured in $\mathrm{mm}$ at the concentration of 150

$\mathrm{mg} / \mathrm{ml}$, for $\left(\mathrm{C}_{4} \mathrm{H}_{12} \mathrm{~N}_{2}\right)_{3}\left[\mathrm{Mn}\left(\mathrm{H}_{2} \mathrm{O}\right)_{6}\right]\left(\mathrm{NO}_{3}\right)_{8}(\mathbf{1})\left(\mathrm{C}_{4} \mathrm{H}_{12} \mathrm{~N}_{2}\right)_{3}\left[\mathrm{Cu}\left(\mathrm{H}_{2} \mathrm{O}\right)_{6}\right]\left(\mathrm{NO}_{3}\right)_{8}(\mathbf{2})$ and

$\left(\mathrm{C}_{4} \mathrm{H}_{12} \mathrm{~N}_{2}\right)_{3}\left[\mathrm{Co}\left(\mathrm{H}_{2} \mathrm{O}\right)_{6}\right]\left(\mathrm{NO}_{3}\right)_{8}(3)$ 


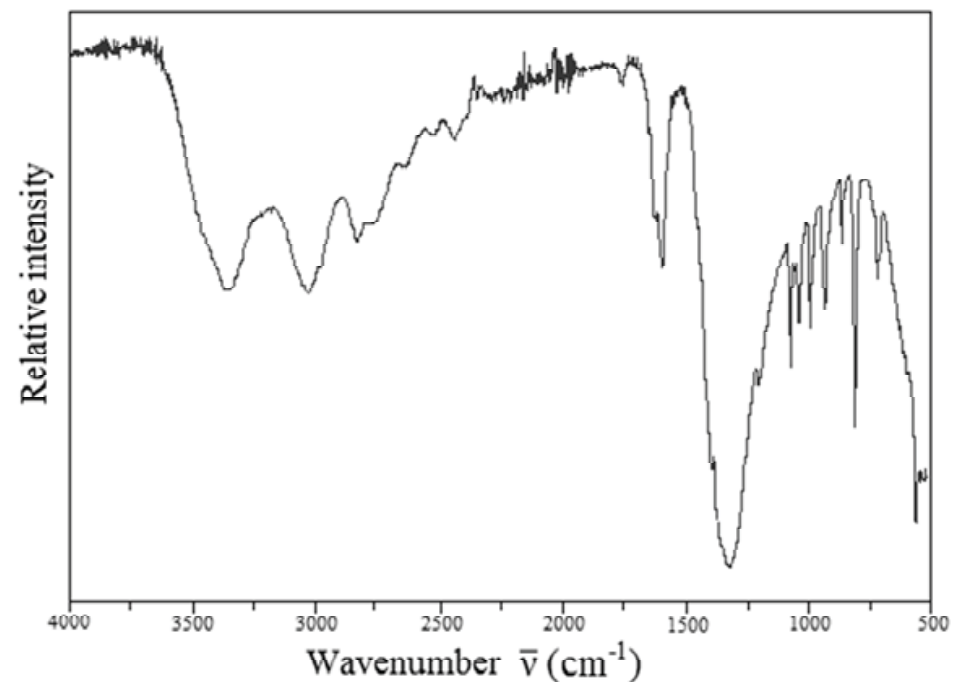

Figure 1

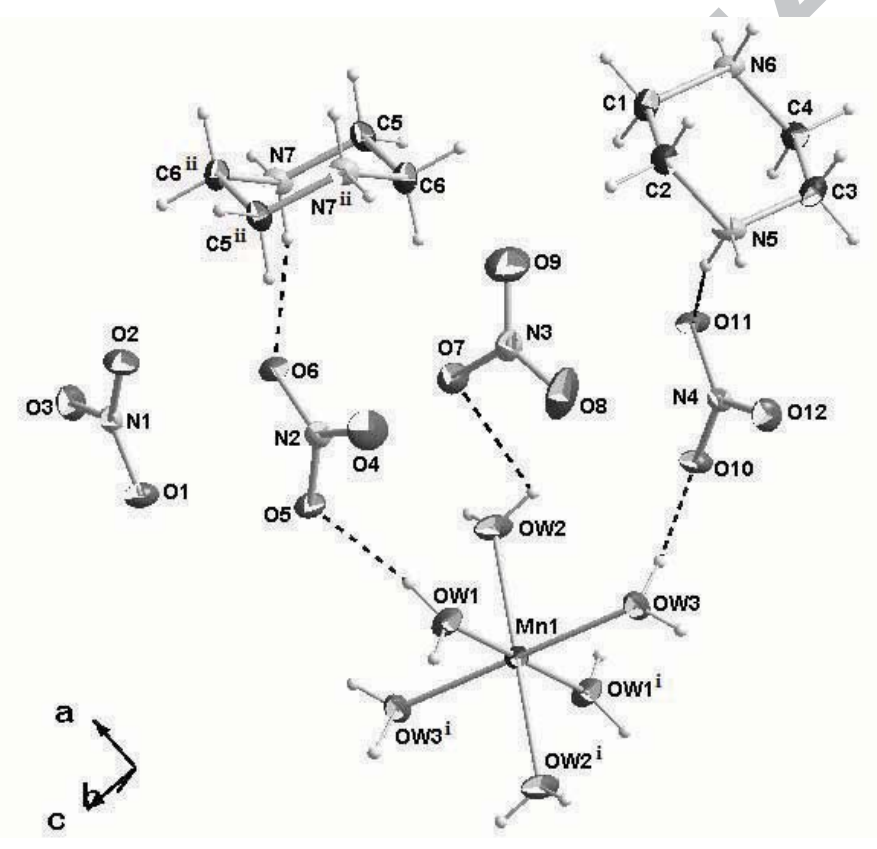

Figure 2 


\section{ACCEPTED MANUSCRIPT}

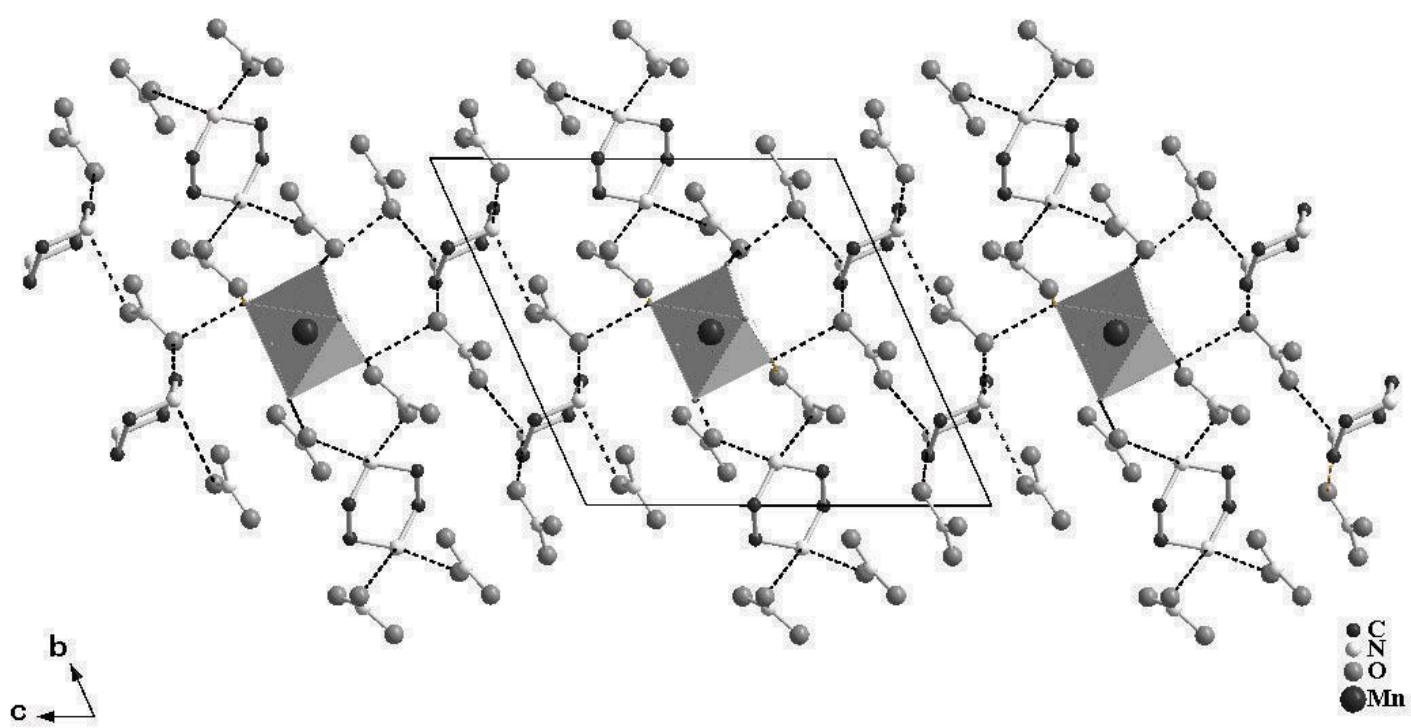

Figure 3

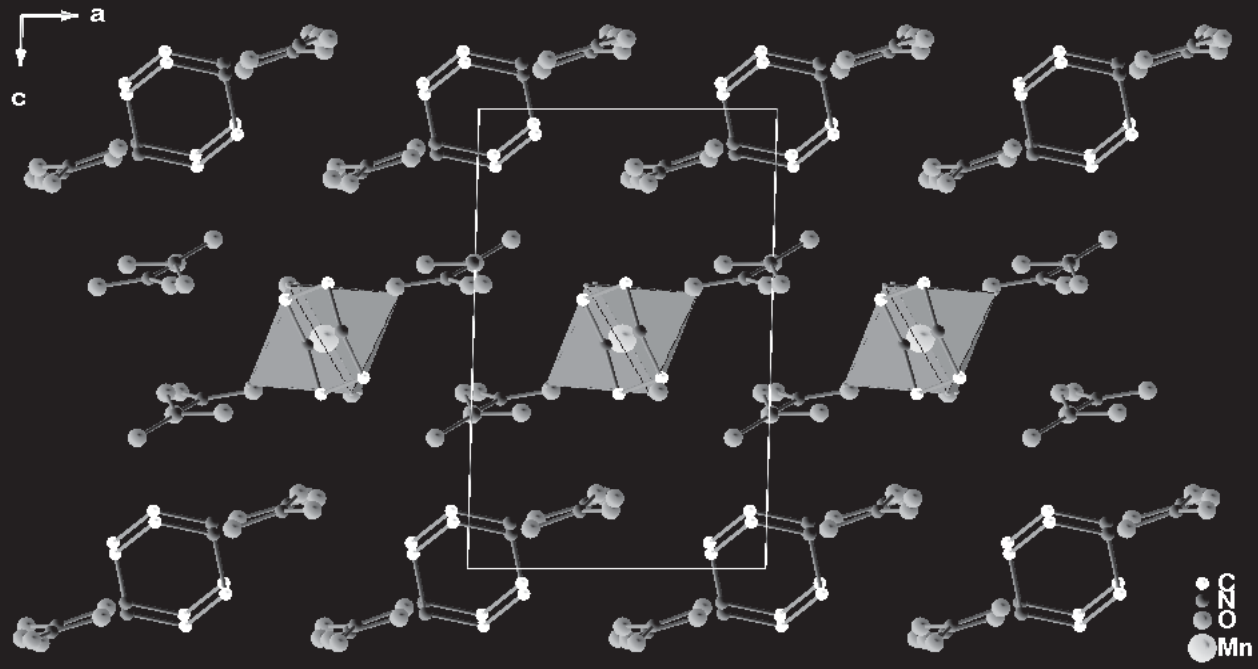

Figure 4 

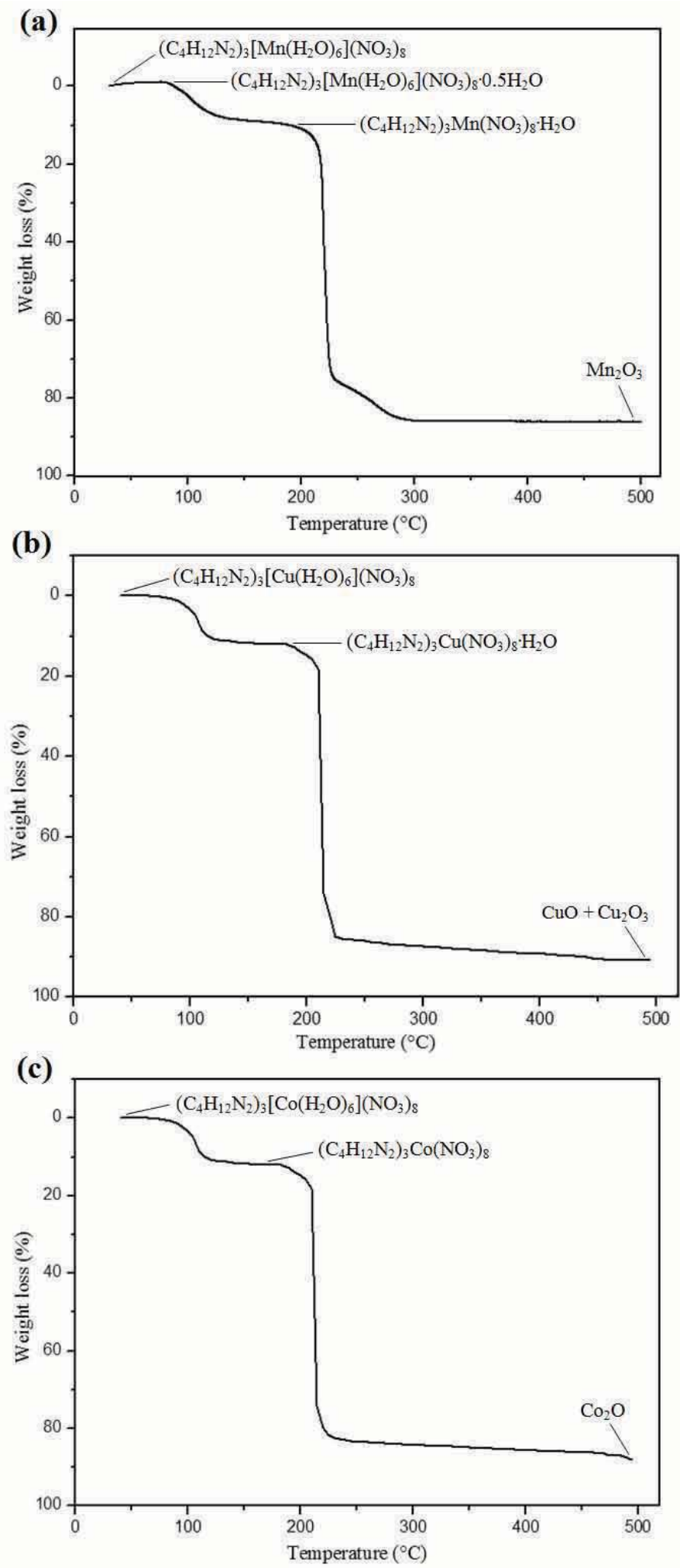

Figure 5 


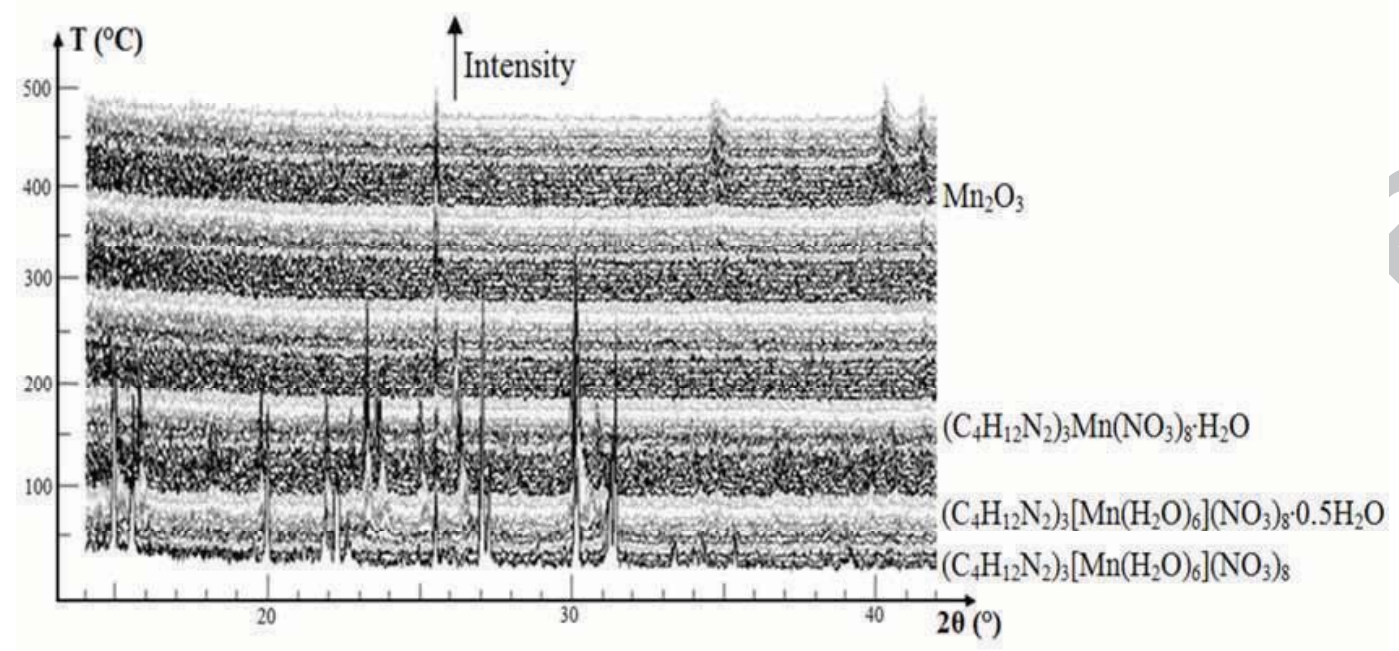

Figure 6

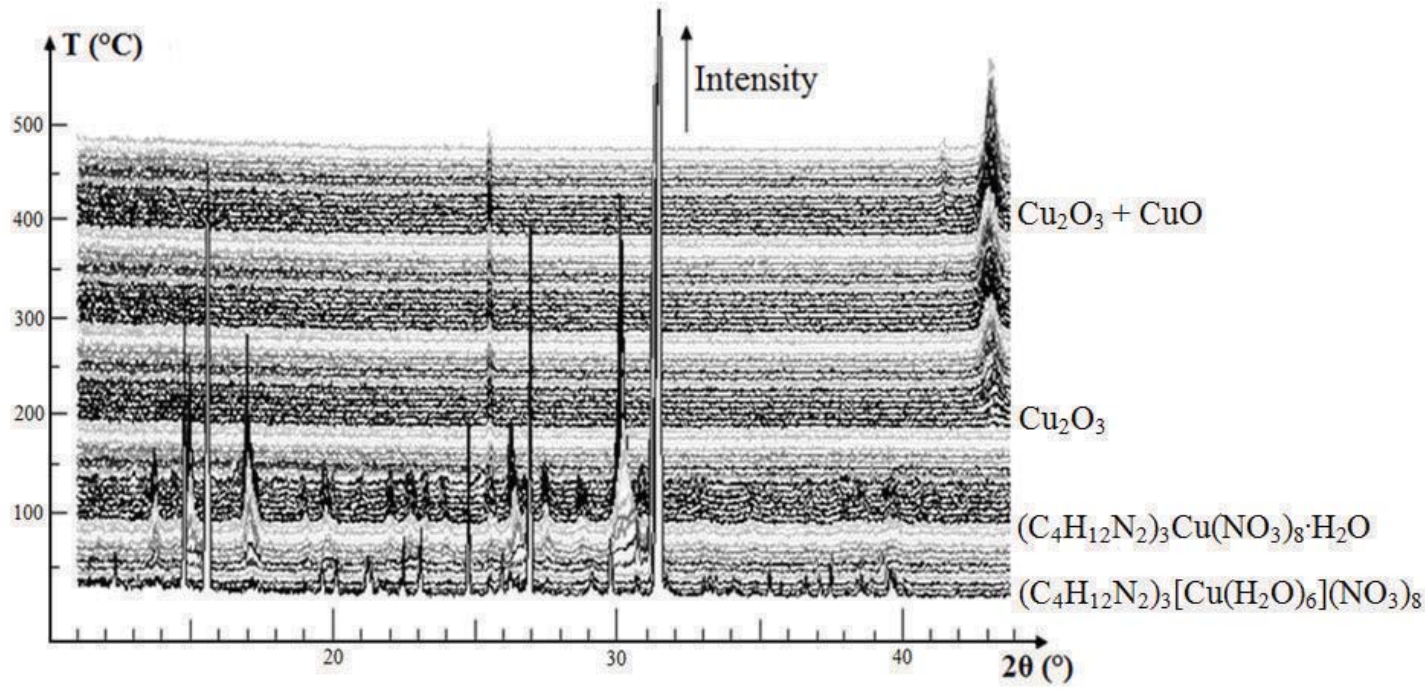

Figure 7 


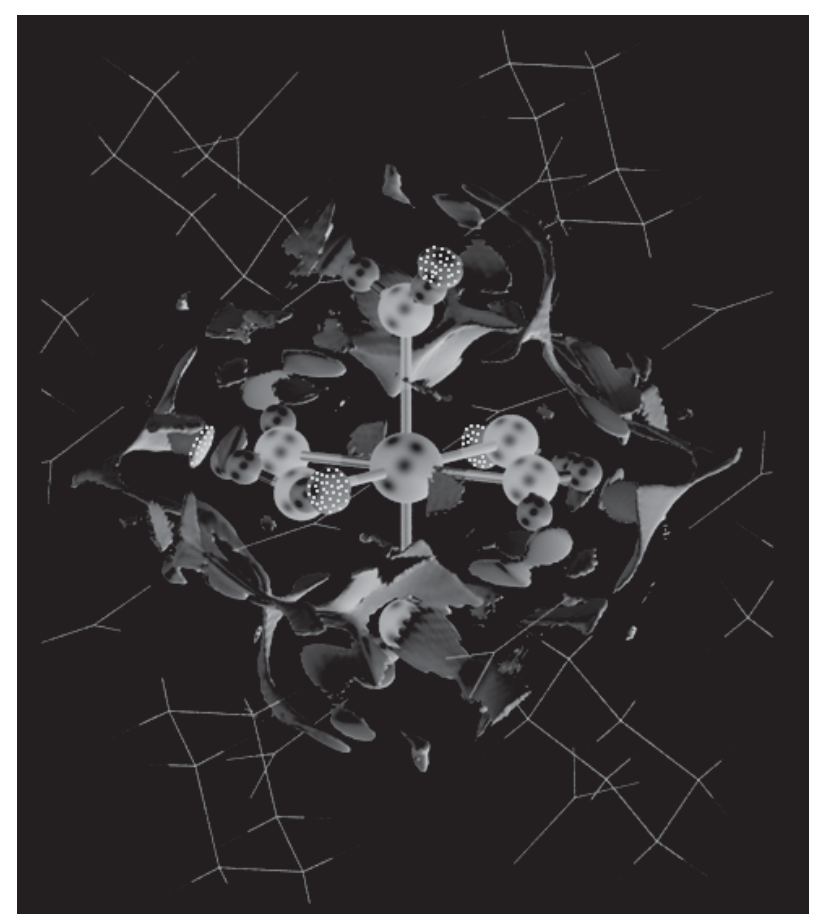

Figure 8 

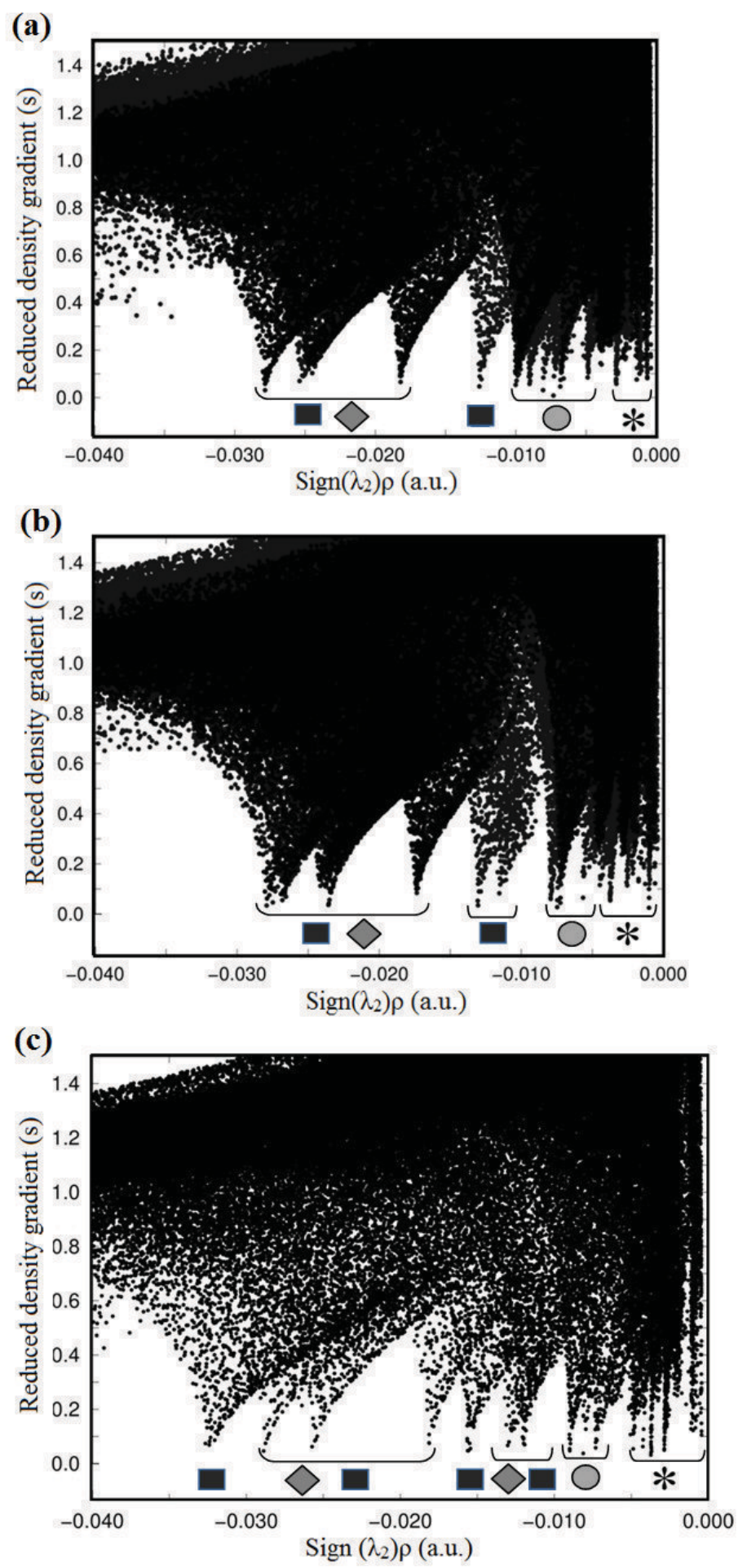

Moderate density attractions

$\mathrm{N}-\mathrm{H} \cdots \mathrm{O}$ hydrogen bonds \OW-H...O hydrogen bonds
Low density attractions

Weak directional interactions

* Van der Waals attractions

Figure 9 


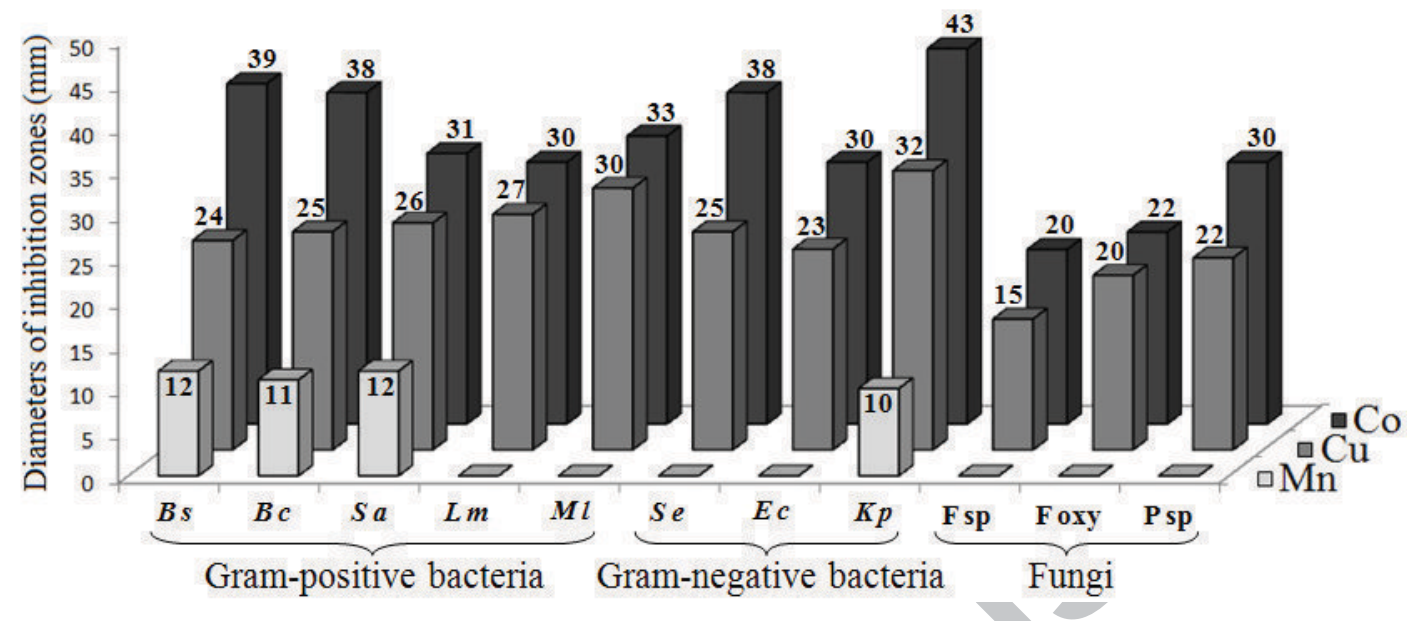

Figure 10 